\title{
Pengaruh Modal dan Tenaga Kerja Terhadap Produksi Sektor Industri Pengolahan di Sumatera Barat
}

\author{
SELLY PRIMA DESWENI \\ Akademi Sekretari dan Manajemen Persada Bunda \\ Jalan Diponegoro No.42 Pekanbaru Riau. Telp: 0761 - 23181 \\ E.mail: selly.prima@yahoo.com
}

\begin{abstract}
Abstract: The purpose of this research is to analyze (1) Influence of amount of capital to production of processing industry in West Sumatera. (2) The influence of labor on the production of processing industry in West Sumatra. (3) Influence of amount of capital and amount of labor to production of processing industry in West Sumatera. This research is classified in Descriptive and Associative research. The type of data is secondary data obtained from the Central Bureau of Statistics of West Sumatra Province. The variables of this study consist of the amount of capital (X1) and the amount of labor (X2) as the independent variable and the amount of production of manufacturing industry (Y) as the dependent variable. Data analysis technique used is (1) Descriptive Analysis and (2) Inductive Analysis consist of multicollonearity test, autocorealsi test, normality test, heterokedastisity test, multiple regression analysis and hypothesis testing (t test and $\mathrm{f}$ test) with $\alpha=0,05$. The result of this research indicates that (1) partially there is significant influence between amount of capital to production of processing industry in West Sumatera $(\mathrm{sig}=0,041)$ with influence level equal to 1,154 . (2) In parsialterdapat significant influence between the amount of labor to the production of processing industry in West Sumatra $(\mathrm{sig}=0.038)$ with an influence level of 3.726. (3) There is a significant influence between the amount of capital and the amount of labor on the production of processing industry in West Sumatera ( $\operatorname{sig}=0.007)$. The joint contribution of the two independent variables to $\mathrm{Y}=42.50 \%$. The authors suggest that the government is asked to be active in giving the capital credit with the interest rate because the processing industry is a promising industry in the future. The government is more vigorous to provide counseling and skills to the workforce so that the quality of the workforce can be improved.
\end{abstract}

\section{Keywords: Capital, Labor, Industrial Sector Production}

Sektor industri pengolahan merupakan komponen utama dalam pembangunan ekonomi nasional. Sektor ini tidak saja berpotensi mampu memberikan kontribusi ekonomi yang besar melalui nilai tambah, lapangan kerja, dan devisa, tetapi juga mampu memberikan kontribusi yang besar dalam transformasi struktural bangsa ke arah modernisasi kehidupan masyarakat yang menunjang pembentukan daya saing nasional. Betapa tidak, sector industry pengolahan mampu mengoptimalkan penggunaan bahan baku menjadi lebih baik dengan daya jual yang tinggi yang diharapkan mampu meningkatkan tambahan keuntungan dan pendapatan Nasional. Oleh karena itu tidak heran bahwa peranan sektor industri pengolahan dalam perekonomian suatu negara lambat laun menjadi semakin penting.

Sumatera Barat termasuk salah satu provinsi yang pertumbuhan ekonominya sedang berkembang. Dengan kekayaan alam yang melimpah, serta ketersediaan sumber daya manusia menjadi modal utama untuk meningkatkan perekonomian daerah. Salah satu prioritas untuk meningkatkan laju pertumbuhan ekonomi di Sumatera Barat adalah meningkatkan pembangunan disektor industri pengolahan. Pembangunan sektor indutri pengolahan diarahkan untuk memanfaatkan potensi sumber daya alam dan potensi sumber daya manusia yang tersedia.

Dalam pelaksanaannya, industri pengolahan mendapat perhatian yang 
cukup dari Dinas Koperasi Perindustrian dan Perdagangan Sumatera Barat. Dengan ketersediaan modal dan tenaga kerja seharusnya industri pengolahan tersebut sudah mampu memberikan kontribusi yang besar terhadap PDRB Sumatera Barat serta menyerap tenaga kerja yang cukup banyak dalam proses produksinya. Pada umumnya permasalahan yang dihadapi oleh industri pengolahan antara lain kurangnya kemampuan adminitrasi usaha, lemahnya kemampuan panalaran, kurangnya modal dari luar karena tidak mengetahui besarnya dana yang dibutuhkan, kurangnya kemampuan untuk mendapatkan informasi dan teknologi yang perlu untuk pengembangan usaha, serta masih rendahnya tingkat pendidikan.

Maju mundurnya suatu industri sangat ditentukan dengan adanya kemampuan untuk memadukan komponen modal dan tenaga kerja, pasar dan transportasi. Jadi dapat disimpulkan jika salah satu komponen tersebut tidak berfungsi, akan berpengaruh terhadap produksi industri tersebut. Permasalahan lain yang sedang dihadapi industri yaitu: kurangnya tenaga kerja yang mengakibatkan produksi kurang lancar, sehingga untuk menghasilkan produk membutuhkan waktu yang lama dan biaya yang tinggi.

Ada beberapa permasalahan yang timbul berkaitan dengan aktifitas produksi pada industry pengolahan dimana ketika modal dan tenaga kerja meningkat, produksi industri pengolahan tidak ikut meningkat dan juga sebaliknya jika modal dan tenaga kerja menurun, produksi industri pengolahan tidak ikut menurun pula. Dari fenomena tersebut terlihat bahwa ada beberapa variabel yang tidak sesuai dengan harapan ataupun teori-teori yang berlaku.

$\begin{array}{lcr}\text { Sektor } & \text { industri } & \text { pengolahan } \\ \text { merupakan } & \text { sektor } & \text { penggerak } \\ \text { perekonomian. } & \text { Dengan } & \text { adanya sektor }\end{array}$ industri pengolahan dapat memperluas lapangan pekerjaan agar pengangguran dapat berkurang, mengingat bertambahnya jumlah penduduk yang berdampak pada jumlah angkatan kerja tiap tahunnya. Selain itu melihat masalah yang dihadapi oleh industri pengolahan ini dalam modal berupa modal dan tenaga kerja untuk memproduksi barang pada masa yang akan datang, maka penulis merasa perlu dilakukan penelitian mengenai industri pengolahan di Sumatera Barat.

Menurut Case and Fair (2002:182) produksi merupakan proses menggabungkan masukan dan mengubahnya menjadi keluaran. Adapun masukan (input) merupakan segala sesuatu yang dibutuhkan dalam proses produksi, hingga menghasilkan suatu keluaran (output) barang atau jasa. Dari pendapat diatas tentang produksi, maka dapat disimpulkan bahwa kegiatan produksi yang dilakukan bertujuan untuk menciptakan nilai tambah dari barang dan jasa dalam rangka meningkatkan pemenuhan atau memuaskan kebutuhan konsumen.

Fungsi produksi adalah hubungan fisik antara variabel yang di jelaskan dan variabel yang menjelaskan. Dimana variabel yang menjelaskan disebut input (X) dan yang di jelaskan adalah output (Y). Dalam penelitian ini yang menjadi input (X) adalah modal dan tenaga kerja, sedangkan hasil produksi sebagai output. Jumlah output selalu tergantung atau merupakan fungsi dari faktor-faktor produksi yang digunakan dalam proses produksi. Hubungan antara output yang dihasilkan dan faktor-faktor yang digunakan ini sering dinyatakan dalam suatu fungsi produksi(production function).

Kemudian Sukirno (2008:195) mengemukakan fungsi produksi sebagai berikut :

$\mathrm{Q}=\mathrm{f}(\mathrm{K}, \mathrm{L}, \mathrm{R}, \mathrm{T})$

Dimana :

$\mathrm{K}=$ jumlah stok modal

$\mathrm{L}=$ jumlah tenaga kerja

$\mathrm{R}=$ kekayaan alam

$\mathrm{T}=$ tingkat teknologi yang digunakan

$\mathrm{Q}=$ jumlah produksi yang dihasilkan

Persamaan tersebut merupakan

suatu pernyataan matematik yang pada

p.ISSN: 2407-800X e.ISSN: 2541-4356 
dasarnya berarti bahwa jumlah modal, jumlah tenaga kerja, jumlah kekayaan alam dan tingkat teknologi sangat berpengaruh terhadap hasil produksi.Jumlah produksi yang berbeda tentunya juga membutuhkan jumlah kombinasi penggunaan faktor-faktor produksi yang berbeda juga.Disamping itu, untuk satu tingkat produksi tertentu, dapat pula digunakan gabungan faktor produksi yang berbeda. Persamaan diatas juga menjelaskan hubungan antara jumlah output (Q) dengan keempat input, yaitu modal (K) dan tenaga kerja (L), kekayaan alam (R) dan tingkat teknologi (T). Ini berarti bahwa hasil produksi suatu barang atau jasa ditentukan oleh kombinasi keempat faktor tersebut.Tetapi dalam penelitian ini peneliti menggunakan dua buah faktor produksi yaitu modal dan tenaga kerja yang mana faktor tersebut berpengaruh terhadap hasil produksi.

Gabungan antara tenaga kerja dan modal yang menghasilkan suatu tingkat produksi tertentu dapat dilihat dalam kurva produksi sama(isoquant). Menurut Sukirno (2003:198), kedua faktor produksi, yaitu modal dan tenaga kerja dapat ditukarkan penggunaannya (bersubstitusi) sehinga akan dapat menghasilkan suatu tingkat produksi tertentu. Dimana semakin jauh dari titik nol letak kurva IQ maka tingkat produksi akan semakin tinggi. Hal ini dapat dijelaskan pada Gambar 1 sebagai berikut:

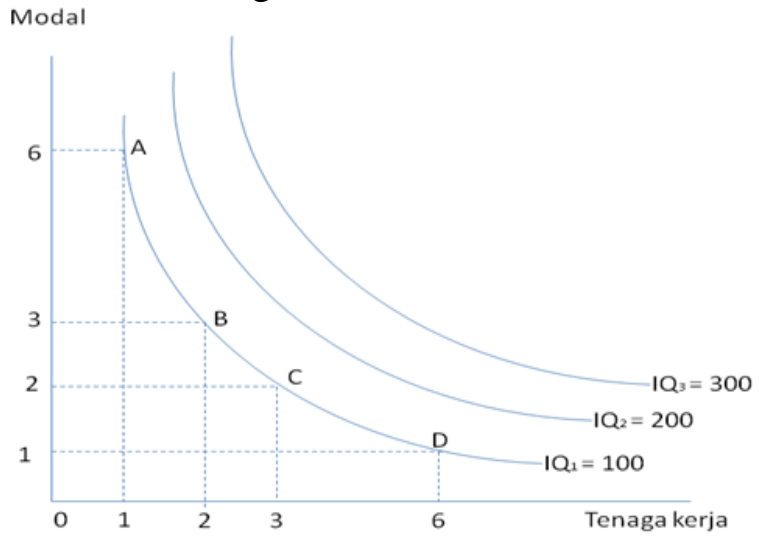

Gambar 1.

Kurva Produksi Sama (Isoquant)

Gabungan A menunjukan bahwa 1 orang tenaga kerja dan 6 modal dapat menghasilkan produksi sebanyak 100 unit.Gabungan B menunjukan bahwa diperlukan 2 orang tenaga kerja dan 3 modal untuk dapat menghasilkan 100 unit produksi.Begitu juga dengan gabungan $\mathrm{C}$ dan D yang sama-sama menghasilkan produksi sebanyak 100 unit produksi. Jadi untuk menghasilkan produksi sebesar 100 unit bisa digunakan gabungan dari dua input faktor produksi yang diinginkan sepanjang kurva isokuan ( $\left.\mathrm{IQ}_{1}\right)$. Disamping itu, kurva $\mathrm{IQ}_{2}$ dan $\mathrm{IQ}_{3}$ menggambarkan tingkat produksi yang berbeda-beda, yaitu berturut-turut sebanyak 200 unit dan 300 unit.Masing-masing kurva tersebut menunjukan gabungan tenaga kerja dan modal yang diperlukan untuk menghasilkan tingkat produksi yang ditunjukkannya.

Pada gambar 1 dapat diambil kesimpulan bahwa berapapun penggunaan modal dan tenaga kerja yang digunakan untuk menghasilkan produksi, maka hasil produksi tersebut akan tetap sebanyak $\mathrm{IQ}_{1}$ yaitu 100. Begitu juga pada kurva isokuan $\mathrm{IQ}_{2}$ yaitu sebesar 200 , dan $\mathrm{IQ}_{3}$ yaitu sebesar 300.

Untuk menghemat biaya produksi dan memaksimalkan keuntungan, perusahaan harus meminimumkan biaya produksi. Untuk membuat analisis mengenai peminimuman biaya produksi perlulah dibuat garis biaya sama (isocost). Garis ini menggambarkan gabungan faktorfaktor produksi yang dapat diperoleh dengan menggunakan sejumlah biaya tertentu. Sukirno (2003:199)

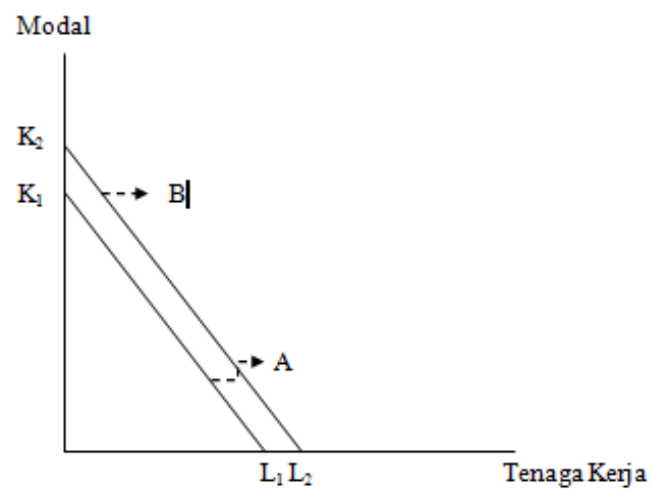

Gambar 2.

Garis Biaya Sama (Isocost)

Garis Isocost yang terendah menunjukkan kemampuan yang dapat dibeli oleh kombinasi $\mathrm{K}_{1}$ dan $\mathrm{L}_{1}$ adalah 
sebesar A. Sedangkan garis kedua menunjukkan kombinasi $\mathrm{K}$ dan $\mathrm{L}$ yang bisa dicapai bila biaya total sebesar B.

Suatu perusahaan berada pada kondisi produksi optimum apabila terjadi persinggungan antara Isocost dan Isoquant. Apabila masing-masing keseimbangan dihubungkan akan terbentuk jalur perluasan produksi dalam jangka panjang. Sukirno (2003:201)

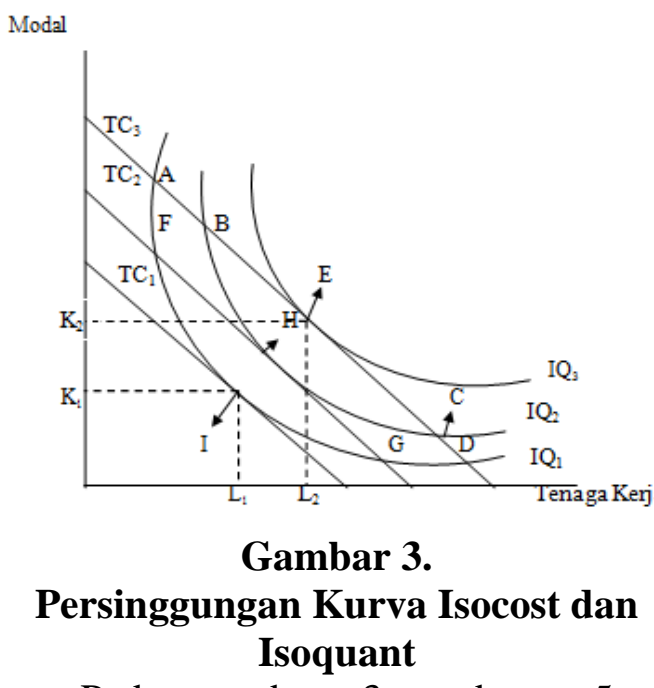

Pada gambar 3 terdapat 5 titik perpotongan dengan garis $\mathrm{TC}_{3}$ yaitu $\mathrm{A}, \mathrm{B}, \mathrm{C}$, $\mathrm{D}$, dan E. Titik E berada pada perpotongan isoquant dan isocost paling tinggi, dengan tingkat produksi sebesar $\mathrm{IQ}_{3}$. Hal ini berarti titik E akan memaksimumkan jumlah produksi, yaitu sebanyak $\mathrm{K}_{2}$ dan $\mathrm{L}_{2}$.

Pada gambar 3 terdapat titik perpotongan garis $\mathrm{TC}_{1}$ yaitu $\mathrm{A}, \mathrm{D}, \mathrm{F}, \mathrm{G}$, dan I. Titik I berada pada kurva produksi sama dengan biaya paling murah sebesar $\mathrm{IQ}_{1}$. Ini berarti titik I akan meminimumkan biaya produksi, yaitu sebanyak $\mathrm{K}_{1}$ dan $\mathrm{L}_{1}$

\section{METODE}

Untuk menganalisa permasalahan dan mencari pemecahan masalah yang diinginkan maka dibutuhkan data akurat karena bila ada data yang diperoleh tidak memenuhi syarat maka analisa yang akan dilakukan menjadi lemah dan berakibat buruk pada pengambilan keputusan-keputusan. Adapun teknik pengumpulan data yang digunakan adalah :

Teknik ini digunakan untuk data sekunder yaitu dengan melakukan pengamatan terhadap data-data dokumenter yang dibuat oleh instansi seperti Badan Statistik Kota Padang. Penelitian ini didukung dengan cara membaca buku dan literatur lainnya yang berhubungan dengan penelitian.

Analisis ini bertujuan untuk membahas hubungan lebih dari dua variabel bebas yaitu dua atau lebih variable independent dan satu variable dependent. Variable dependent (terikat) dalam penelitian ini adalah produksi sektor industri pengolahan diSumatera Barat dan variable independent (bebas) yaitu modal dan jumlah tenaga kerja.maka fungsi produksi Cobb-Douglas.

\section{HASIL}

Dari hasil estimasi data tersebut dapat dibuat persamaan dari analisis regresi linear berganda, yaitu sebagai berikut :

$\log \hat{Y}=-16,293+1,154 \operatorname{LogX} 1+3,726$ $\operatorname{LogX} 2$

Dalam regresi tersebut diperoleh nilai $\alpha+\beta>1$, artinya hasil atas skala produksi Industri pengolahan di Sumatera Barat berada pada kondisi Increasing return to scale (IRTS) yang berarti bila semua faktor produksi dinaikan sebesar 1\%, maka output yang dihasilkan akan meningkat lebih besar dari 1\%.Besaran nilai tersebut akan tetap mesikipun terjadi peningkatan atau penurunan penggunaan modal dan tenaga kerja.

Selanjutnya dari hasil pengujian dapat diketahui bahwa bentuk pengaruh modal (X1) terhadap hasil produksi adalah positif dengan koefisien regresi sebesar 1,154. Ini berarti apabila variabel modal ditingkatkan sebesar satu persen maka hasil produksi akan mengalami peningkatansebesar 1,154 persen. Hal ini menunujukan bahwa ketika penggunaan modal semakin meningkat maka hasil produksi juga akan meningkat berlakunya asumsi cateris paribus. Sedangkan bentuk pengaruh jumlah tenaga kerja (X2) terhadap hasil produksi Industri pengolahan berdasarkan hasil analisis regresi adalah positif dengan nilai koefisien regresi, yaitu 
3,726. Artinya pada kondisi saat sekarang ini bila penggunaan tenaga kerja ditingkatkan sebesar satu persen, maka akan menyebabkan kenaikan hasil produksi sebesar 3,726 persen dengan asumsi cateris paribus.

Selain itu, nilai produksi elastis terhadap modal industri pengolahan di Sumatera Barat $(1,154>1)$, sebab terdapat variabel lain yang menggantikan modal, sehingga nilai produksi cenderung untuk elastis terhadap modal. Nilai produksi juga elastis terhadap jumlah tenaga kerja pada industri pengolahan di Sumatera Barat $(3,726$ $>1$ ), sebab terdapat variabel lain yang dapat menggantikan tenaga kerja, sehingga nilai produksi juga cenderung untuk elastis terhadap jumlah tenaga kerja.

Adapun hipotesis pertama adalah secara parsial jumlah modal berpengaruh signifikan terhadap hasil produksi Industri pengolahan di Sumatera Barat. Dapat dilihat bahwa nilai $t_{\text {hit }} 2,195>t_{\text {tab }} 1,734$ atau sig $0,041<0,05$, oleh karena itu hipotesis nol ditolak dan hipotesis alternatif diterima. Artinya hasil produksi industri pengolahan di Sumatera Barat dipengaruhi oleh jumlah modal dengan asumsi jumlah tenaga kerja tetap.

Hipotesis kedua adalah secara parsial jumlah tenaga kerja berpengaruh signifikan terhadap hasil produksi Industri pengolahan di Sumatera Barat. Hasil pengujian menunjukan bahwa nilai $t_{\text {hit }} 2,245>t_{\text {tab }} 1,734$ atau sig $0,038<0,05$ dengan demikian hipotesis nol ditolak dan hipotesis alternatif diterima. Artinya hasil produksi Industri pengolahan di Sumatera Barat dipengaruhi oleh jumlah tenaga kerja dengan asumsi jumlah modal tetap.

Hipotesis yang ketiga dalam penelitian ini adalah secara bersama-sama terdapat pengaruh yang signifikan antara modal dan tenaga kerja terhadap hasil produksi Industri pengolahan di Sumatera Barat. Dalam pengujian ini diperoleh nilai $\mathrm{F}_{\text {hit }} 6,645>\mathrm{F}_{\mathrm{tab}} 3,55$ dan signifikan $0,007<$ 0,05 yang berarti hipotesis alternatif diterima. Artinya hasil produksi Industri pengolahan di Sumatera Barat dipengaruhi secara bersamasama oleh jumlah modal dan tenaga kerja.

\section{PEMBAHASAN}

Pengaruh Modal (X1) terhadap Hasil Produksi Industri Pengolahan di Sumatera Barat

Berdasarkan hasil analisis regresi bahwa hipotesis nol ditolak dan hipotesis alternatif diterima, ini berarti bahwa modal berpengaruh signifikan terhadap hasil produksi Industri pengolahan di Sumatera Barat. Artinya perubahan penggunaan modal mengakibatkan berubahnya output yang dihasilkan, bila modal yang digunakan dalam proses produksi besar maka jumlah kuantitas output yang dihasilkan juga akan lebih besar, sebaliknya modal yang kecil akan menghasilkan output dalam jumlah yang sedikit. Dengan kata lain, jumlah modal yang tersedia dapat menggambarkan seberapa besar output mampu dihasilkan oleh suatu perusahaan dengan modal yang ada. Jadi bagi perusahaan yang ingin meningkatkan dan mengembangkan usahanya perlu memiliki ketersediaan modal yang cukup, agar pengembangan dan peningkatan usaha dapat tercapai sesuai dengan perencanaan.

Dalam perindustrian, besar kecilnya jumlah modal yang dimiliki oleh pengusaha atau perusahaan sangat menentukan masa depan dari perusahaan tersebut. Jika perusahaan memiliki modal yang cukup besar, maka perusahaan tersebut akan dapat bertahan di pasar, karena perusahaan akan mampu menghadapi masalah-masalah yang timbul dari dalam perusahaan itu sendiri maupun dari pesaing yang ada dengan mengandalkan modal dan strategi-strategi yang telah dipersiapkan. Namun ketika suatu perusahaan tidak memiliki modal yang cukup dalam melakukan produksi, maka perusahaan tersebut akan terancam keberlangsungannya. Untuk itu perlu perhitungan yang tajam dan strategi yang tepat dalam melakukan proses produksi, agar suatu perusahaan tidak mengalami kerugian yang mengakibatkan perusahaan harus keluar dari pasar.

Dalam proses produksi Industri pengolahan yang ada di Sumatera Barat

$$
\text { p.ISSN: } 2407-800 X \quad \text { e.ISSN: } 2541-4356
$$


juga tidak terlepas dari permasalahan ketersediaan modal, apabila modal yang akan digunakan dalam proses produksi tidak ada atau kecil, maka akan mengakibatkan lambatnya perkembangan hasil produksi, begitu juga dengan kontribusi sektor tersebut terhadap pertumbuhan ekonomi akan kecil di Sumatera Barat. Untuk itu, diperlukan adanya Investor dalam penyediaan modal pada Industri pengolahan di Sumatera Barat, agar masalah kekurangan modal dapat teratasi. Apabila modal yang dibutuhkan dalam proses produksi tersebut telah tersedia maka perusahaan atau pelaku usaha akan mampu meningkatkan hasil produksinya yang pada akhirnya berdampak terhadap peningkatan pertumbuhan ekonomi di Sumatera Barat.

Dapat disimpulkan bahwa kelancaran suatu proses produksi sangat ditentukan oleh ketersediaan modal yang dimiliki oleh suatu perusahaan. Dimana modal yang tersedia dengan jumlah besar akan dapat meningkatkan hasil produksi serta perusahaan dapat berkembang dengan cepat dan mampu bersaing dengan perusahaan lain yang ada di dalam maupun di luar Sumatera Barat itu sendiri. Disamping itu, peningkatan modal akan berarti apabila permintaan masyarakat terhadap barang atau jasa yang dihasilkan oleh sebuah industri juga meningkat. Artinya peningkatan hasil produksi dan penggunaan modal sangat tergantung pada permintaan konsumen.

Pengaruh Tenaga Kerja (X2) terhadap Hasil Produksi Industri Pengolahan di Sumatera Barat

Hipotesis alternatif yang diajukan dalam penelitian diterima, dimana tenaga kerja berpengaruh signifikan terhadap hasil produksi Industri pengolahan di Sumatera Barat, adapun bentuk pengaruh tenaga kerja terhadap hasil produksi adalah positif artinya apabila tenaga kerja ditingkatkan maka hasil produksi Industri pengolahan juga akan meningkat, sebaliknya mengurangan tenaga kerja akan menyebabkan hasil produksi juga meningkat.

Meningkatnya jumlah produksi yang dihasilkan dengan mutu yang baik tentu akan meningkatkan nilai jual dari produksi tersebut, sehingga menghasilkan nilai output yang tinggi. Hal ini tentu akan meningkatkan pendapatan dari industri pengolahan, sehingga kesejahteraan tenaga kerja yang bekerja pada industri ini akan meningkat. Ketika penambahan penggunaan tenaga kerja tersebut adalah orang yang ahli dibidangnya, maka akan mampu menciptakan produktifitas tinggi, ini berarti hasil produksi bisa ditingkatkan. Industri pengolahan memiliki potensi untuk dikembangkan dalam rangka menciptakan pertumbuhan ekonomi yang lebih baik di Sumatera Barat. Hal ini tentu tidak terlepas dari upaya-upaya yang dilakukan oleh pemerintah untuk memperlancar proses produksi Industri pengolahan tersebut.

Dengan kata lain tenaga kerja merupakan salah satu faktor penting dalam kegiatan produksi suatu industri. Dengan tenaga kerja yang berpengalaman dibidangnya dan bekerja secara efektif dan efisien maka akan lebih dapat meningkatkan jumlah produksi. Hal tersebut sudah tentu nantinya pada masa yang akan datang dapat meningkatkan keuntungan bagi industri pengolahan ini. Walaupun bergitu, tenaga kerja sangat berperan penting dalam menghasilkan output, ini terbukti dari hasil penelitian bahwa pengaruh tenaga kerja berpengaruh signifikan terhadap hasil produksi pengolahan di Sumatera Barat.

Pengaruh Modal dan Tenaga Kerja terhadap Produksi Industri Pengolahan di Sumatera Barat

Berdasarkan hasil uji hipotesis yang dilakukan bahwa terdapat pengaruh yang signifikan antara modal (X1) dan tenaga kerja (X2) terhadap jumlah produksi industri pengolahan di Sumatera Barat (Y).Diterimanya hipotesis tersebut juga dapat dibuktikan dengan melihat bahwa $F_{\text {hitung }}>F_{\text {tabel }}$ hal tersebut membuktikan bahwa terdapatnya pengaruh positif secara bersama-sama antara modal dan tenaga kerja terhadap produksi industri pengolahan

p.ISSN: $2407-800 X \quad$ e.ISSN: 2541-4356 
di Sumatera Barat.Ini mengindikasikan bahwa untuk jumlah produksi industri pengolahan di Suimatera Barat harus ditingkatkan oleh jumlah modal dan jumlah tenaga kerja pada industry pengolahan tersebut.

Besarnya sumbangan secara bersamasama dari variabel (X1) dan (X2) terhadap (Y) adalah 42,50 persen. Ini berarti variabel meningkat atau menurunnya jumlah produksi industri pengolahan di Sumatera Barat ini disumbangkan oleh modal dan tenaga kerja yang terdapat pada industri pengolahan di Sumatera Barat. Sedangkan selebihnya sebesar 57,50 persen dipengaruhi oleh variabel lain yang tidak diteliti, seperti bahan baku, teknologi dan dan lainnya yang mempengaruhi jumlah produksi industri pengolahan di Sumatera Barat ini.

Senada dengan itu Nicholson (2002: 181) juga menyatakan bahwa produksi pada sebuah perusahaan sangat dipengaruhi oleh modal dan tenaga kerja yang dinyatakan dalam fungsi $\mathrm{Q}=\mathrm{f}(\mathrm{K}, \mathrm{L})$. karena modal dan tenaga kerja merupakan input langsung yang mempengaruhi jumlah produksi yang dihasilkan.Apabila jumlah modal yang tersedia mencukupi dengan tenaga kerja yang berkualitas maka jumlah produksi meningkat. Dengan demikian dapat dikatakan bahwa kombinasi yang baik antara modal dan tenaga kerja akan mampu meningkatkan jumlah produksi industri pengolahan di Sumatera Barat.

Berdasarkan persamaan regresi di atas dapat dibandingkan pengaruh $\mathrm{X} 1$ terhadap Y, dimana tenaga kerja (X2) memiliki pengaruh yang sangat besar terhadap produksi industri pengolahan di Sumatera Barat dengan nilai korelasi secara parsial tenaga kerja adalah sebesar 0,2116 persen, sebaliknya modal memiliki pengaruh yang kecil terhadap produksi industri pengolahan di Sumatera Barat dengan korelasi secara parsial adalah sebesar 0,2190. Hal ini berarti bahwa tenaga kerja lebih dominan menentukan jumlah produksi industri pengolahan di Sumatera Barat. Dan sebaliknya modal kurang dominan dalam menentukan jumlah produksi industri pengolahan di Sumatera Barat.

\section{SIMPULAN}

Berdasarkan hasil penelitian dan analisis data yang telah dilakukan dapat diambil kesimpulan sebagai berikut : Secara parsial jumlah modal (X1) berpengaruh signifikan terhadap hasil produksi Industri pengolahan di Sumatera Barat (Y) pada taraf signifikansi $0,041<\alpha=0,05$, yang artinya jika penggunaan modal ditingkatkan, maka akan menyebabkan hasil produksi meningkat, sebaliknya penurunan penggunaan modal mengakibatkan turunnya hasil produksi Industri pengolahan di Sumatera Barat dengan asumsi cateris paribus. Dengan tingkat pengaruh modal terhadap produksi industri pengolahan di Sumatera Barat adalah sebesar 1,154 persen. Secara parsial jumlah tenaga kerja (X2) berpengaruh signifikan terhadap hasil produksi Industri pengolahan di Sumatera Barat (Y) pada taraf signifikansi $0,038<\alpha=0,05$, artinya jika penggunaan tenaga kerja ditingkatkan, maka akan menyebabkan hasil produksi akan meningkat, sebaliknya pengurangan penggunaan tenaga kerja akan mengakibatkan turunnya hasil produksi Industri pengolahan di Sumatera Barat dengan asumsi cateris paribus.Dengan tingkat pengaruhtenaga kerja terhadap produksi industri pengolahan di Sumatera Barat adalah sebesar 3,726 persen. Secara bersama-sama jumlah modal (X1) dan tenaga kerja (X2) berpengaruh signifikan terhadap hasil produksi Industri pengolahan di Sumatera Barat (Y) dengan taraf signifikansi $0,007<\alpha=0,05$, artinya hasil produksi (Y) dipengaruhi oleh jumlah modal dan jumlah tenaga kerja dengan sumbangan secara bersama-sama sebesar $42,50 \%$.

p.ISSN: $2407-800 \mathrm{X}$

e.ISSN: 2541-4356 


\section{DAFTAR RUJUKAN}

Agung, I Gusti Ngurah. (2008). Teori Ekonomi Mikro Suatu Analisis ProduksiTerapan. Jakarta: PT. Raja Grafindo Persada.

Akhirmen. (2005). Statistika 1. Padang: FE UNP.

Badan Pusat Statistik. (2009-2016). Sumatera Barat dalam Angka. Sumatera Barat:Padang.

, (1987-2016). Statistik Industri Pengolahan di Sumatera Barat. Sumatera Barat: Padang.

Case, Karl E and Ray C. Fair. (2002). Prinsip-Prinsip Ekonomi Mikro Edisi lima. PT. Prenhallindo: Jakarta.

Gujarati, Damodar, N. (2007). Dasar-Dasar Ekonometrika Edisi Ketiga. Jakarta: PT. Gelora Aksara Pratama.

Mulyadi. (2003). Ekonomi Sumber Daya Manusia. PT. RajaGarfindo Persada: Jakarta.

Nachrowi, Djalal and Hardius Usman. (2005). Penggunaan Teknik Ekonometri. Jakarta: PT. Raja Grafindo Persada.

Nazir. (2003). Metode Penelitian. Ghalia Indonesia: Jakarta.
Nicholson,Walter. (2002). Mikroekonomi Intermediate Edisi Kedelapan. Erlangga: Jakarta.

Pyndick dan Rubinfield. (2003). Mikro Ekonomi. PT. Indeks: Jakarta.

(2007).Mikroekonomi

Edisi keenam. PT. Indeks: Jakarta

Rosyidi, Suherman. (2003). Pengantar Teori Ekonomi. PT. Raja Grafindo Persada: Jakarta.

Salvatore, Dominick. (2007). Manajerial Economoics Dalam Perekonomian Global Edisi Keempat. Erlangga: Jakarta.

Sukirno, Sadono. (2003). Pengantar Teori Makro EkonomiEdisi Ketiga. PT. RajaGrafindo Persada: Jakarta

.(2008). Mikro ekonomi Teori Pengantar Edisi Ketiga. PT. RajaGarfindo Persada: Jakarta.

Todaro, Michael P. (2003). Pembangunan Ekonomi di Dunia Ketiga. Erlangga: Jakarta. 